\title{
HUBUNGAN ANTARA KESELAMATAN DAN KESEHATAN KERJA PERAWAT DENGAN TINGKAT KEPUASAN PASIEN
}

\author{
Sri Lailan Nazmi Saragih \\ Email : lailansaragih9@gmail.com
}

\begin{abstract}
ABSTRAK
Kesehatan kerja merupakan suatu kondisi yang bebas dari suatu gangguam secara fisik yang disebabkan oleh lingkungan kerja. Sedangkan, Keselamatan Kerja adalah keselataman yang berhubungan dengan aktivitas kerja manusia di berbagai bidang. Keselamatan dan Kesehatan kerja sangat berperan penting dalam dunia kerja saat ini, khususnya di Institusi Kesehatan. Kecelakaan kerja lebih dominan terjadi di institusi kesehatan seperti rumah sakit. Hal ini dikarenakan rumah sakit merupakan unit pelayanan kesehatan yang memberikan pelayanan terhadap semua jenis penyakit. Oleh karena itu, pihak rumah sakit harus benar-benar memperhatikan dan menyediakan perlindungan bagi semua pasien dan tenaga kerja dari kecelakaan kerja di rumah sakit. Dalam jurnal ini saya akan melakukan penelitian serta mengumpulkan informasi dari berbagai literature view yang kemudian akan dibuat kesimpulan.
\end{abstract}

\section{Kata Kunci : Kesehatan Kerja, Keselamatan Kerja, Kepuasan Pasien}

\begin{abstract}
Occupational health is a condition that is free from physical disturbances caused by the work environment. Meanwhile, work safety is safety related to human work activities in various fields. Occupational safety and health plays an important role in today's world of work, especially in Health Institutions. Work accidents are more dominant in health institutions such as hospitals. This is because the hospital is a health service unit that provides services for all types of diseases. Therefore, the hospital must really pay attention and provide protection for all patients and workers from work accidents in the hospital. In this journal I will conduct research and collect information from various literature views and then draw conclusions.
\end{abstract}

Key Words : Occupational Health, Work Safety, Patient Satisfaction 


\section{LATAR BELAKANG}

Pada zaman sekarang, setiap organisasi maupun institusi akan selalu berhadapan dengan permasalahan yang berkaitan dengan sumberdaya manusia. Suatu perusahaan akan di tuntut untuk memberikan pelayanan yang baik bagi customer. Begitu juga dengan rumah sakit, tenaga kesehatan baik itu dokter, perawat atau staff lainnya pasti akan memberikan pelayanan terbaik bagi pasien. Untuk itu, setiap institusi rumah sakit harus menerapkan keselamatan dan kesehatan kerja guna meningkatkan kepuasan pasien.

Rumah sakit merupakan suatu organisasi yang memberikan pelayanan jasa yang menjalankan fungsinya agar terus tumbuh dan berkembang. Rumah sakit sangat membutuhkan tenaga kerja yang berkualitas untuk mencapai tujuan yang diharapkan oleh pihak rumah sakit maka dapat dilakukan dengan cara membentuk suatu kepuasan kerja pada perawatnya. Dengan adanya kepuasan kerja perawat maka di harapkan mereka dalam menjalankan tugas nya dengan baik. Untuk mewujudkan nya di perlukan tingkat pelayanan yang berkualitas yang dibutuhkan perawat untuk memiliki kemampuan dalam menarik dan mempertahankan tenaga kerja yang berkualitas. Keselamatan dan kesehatan kerja (K3) adalah suatu program yang dibuat pekerja maupun pengusaha sebagai upaya mencegah timbulnya kecelakaan akibat kerja dan penyakit serta tindakan antisipatif apabila terjadi kecelakaan dan penyakit kerja. Tujuannya adalah untuk menciptkan tempat kerja yang nyaman, dan sehat sehingga dapat menekan serendah mungkin resiko kecelakaan dan penyakit. Kepuasan kerja dari setiap tenaga perawat dapat dilihat dari besar kecilnya kesenjangan antara harapan yang diinginkan dengan kenyataan yang diterima. Pelayanan keperawatan perlu upaya peningkatan mutu pelayanan rumah sakit melalui upaya peningkatan kualitas pelayanan keperawatan, dan profesionalisme perawat dalam memberikan dan mengatur kegiatan asuhan keperawatan kepada pasien. Untuk menciptakan perawat agar selalu berupaya memberikan pelayanan yang terbaik bagi pasien , maka pihak rumah sakit atau institusi harus menggunakan kewenangan untuk mengubah sikap dan perilaku karyawan agar berusaha lebih giat dan berkeinginan untuk mencapai hasil yang optimal. Dengan terciptanya kepuasan bagi perawat maka dengan tidak langsung perawat mampu memberikan kinerja yang berkualitas kepada pasien sehingga menjadi kepuasan bagi pasien.

\section{METODE PENELITIAN}

Pengkajian ini menggunakan metode kualitatif yang dilakukan dengan cara mengumpulkan sebanyak-banyaknya data untuk dianalisis, yaitu dengan menggunakan literature view yang berkenaan dengan judul pembahasan yaitu mengenai Proses Keperawatan. Adapun Literature View yang digunakan adalah Buku Teks, Buku Referensi, Jurnal Elektronik, Reasearch, dan hasil skripsi. Dengan kata kunci Peran, Kualitas Pelayanan, dan Keperawatan. Dan Literature View yang digunakan dalam metode ini adalah sebanyak 11 Literature View yang diterbitkan 8 tahun terakhir. 


\section{HASIL}

Berdasarkan dari 11 litrerature yang saya abaca dan fahami didapatkan bahwa Keselamatan dan kesehatan kerja perawat sangat erat hubungan nya dengan kepuasan pasien. Rumah sakit dinyatakan berhasil, tidak hanya dilihat dari segi kelengkapan fasilitasnya, melaikan juga sikap dan layanan sumber daya manusia merupakan elemen yang berpengaruh terrhadap pelayanan yang dihasilkan oleh pihak rumah sakit. Bila elemen ini dihilangkan maka pihak rumah sakit akan kehilangan banyak pasien dan dijauhi oleh calon pasien karena pelayanan nya yang tidak baik. Pasien akan beralih kerumah sakit lain yang dapat memberikan pelayanan terbaik dan tentunya memenuhi harapan pasien terhadap pelayanan rumah sakit. Jika keselamatan dan kesehatan kerja dilakukan dengan baik maka akan memberikan pelayanan yang mengutamakan keselamatan dan kualitas yang optimal, terutama bagi masyarakat akan mendapatkan pelayanan yang berkualitas, aman, dan memenuhi harapan mereka. Bagi tenaga kesehatan, khususnya perawat dapat memenuhi nilai-nilai baru yaitu arti penting penerapan keselamatan pasien dalam setiap aktivitas pelayanan yang diberikan.

Pengetahuan perawat tentang keselamatan dan kesehatan kerja sangat memengaruhi kepuasan pasien terhadap pelayanan dirumah sakit. Karena perawat yang memiliki pengetahuan yang baik mengenai hal ini, maka akan lebih mudah menerapkan nya. Contoh nya menerapkan patient safety. Apabila perawat menerapkan patient safety didasari oleh pengetahuan yang memadai, maka penerapan patient safety oleh perawat akan bersifat langgeng (long lasting).

\section{PEMBAHASAN}

\section{A. Kesehatan dan Keselamatan Kerja}

Kesehatan kerja adalah suatu kondisi yang bebas dari ganguan secara fisik dan psikis yang disebabkan oleh lingkungan kerja. Resiko kesehatan dapat terjadi karena adanya faktor -faktor dalam lingkungan kerja yang bekerja melebihi periode waktu yang ditentukan dan lingkungan yang menimbulkan stres atau gangguan fisik. M Yani ( 2012 ).

Menurut Atika Puspita Sari ( 2012 ) Keselamatan kerja telah menjadi salah satu hak azasi manusia yang harus dilindungi oleh pemerintah dan dihargai oleh anggota masyarakat lainnya. Tenaga kerja harus memperoleh perlindungan dari berbagai soal di sekitarnya dan pada dirinya yang dapat menimpa atau mengganggu dirinya serta pelaksanaan pekerjaannya ( Mondy 2008 ).

Tujuan dari Kesehatan dan Keselamatan Kerja

1. Agar setiap pegawai mendapat jaminan kesehatan dan keselamatan kerja baik secara fisik, sosial dan psikologis.

2. Agar setiap perlengkapan dan peralatan kerja digunakan sebaik - baiknya dan seektif mungkin.

3. Agar semua hasil produksi dipeliharan keamanannya.

4. Agar adanya jaminan atas pemeliharaan dan peningkatan kesehatan gizi pegawai. 


\section{B. Kepuasan Pasien terhadap Penerapan Keselamatan dan Kesehatan Kerja di Rumah Sakit}

Dari beberapa Literature yang saya baca, Tingkat kepuasan pasien terhadap pelayanan keperawatan di Indonesia mayoritas masih kurang puas. Penyebab ketidakpuasan pasien diantaranya faktor kesalahan identifikasi, komunikasi, pemberian obat, dan risiko jatuh. Penelitian ini bertujuan untuk mengidentifikasi hubungan penerapan keselamatan pasien dengan kepuasan pasien di Rumah Sakit.

Keunggulan pelayanan dirumah sakit tidak akan terwujud jika salah satu prinsip pelayanan ada yang di anggap lemah. Faktanya, pasien biasanya memiliki pengalaman yang tidak menyenangkan dirumah sakit, bahkan juga pengalaman yang sangat menakutkan ketika datang kerumah sakit. Hal ini terjadi karena pelayanan yang didapatkan tidak maksimal dan cenderung merugikan pasien. Dari beberapa pernyataan pasien menyampaikan bahwa diantara tenaga kesehatan, salah satunya perawat terkesan terburu-buru dan tidak hati-hati dalam memberikan asuhan keperawatan, sehingga asuhan keperawatan yang didapatkan tidak optimal. Pasien sangat berharap terjadinya interaksi yang baik, sopan, ramah, nyaman dengan perawat sehingga kompetensi, kualifikasi, serta kepribadian yang baik dari pelayanan kesehatan. Faktor utama dalam mempengaruhi kepuasan pasien adalah lengkapnya peralatan medic, bangunan dan fasilitas rumah sakit yang memadai, kelengkapan sarana pendukung dalam pelayanan, dan terhidar dari kecelakaan saat menjalani proses perawatan dirumah sakit.

Pemerintah melakukan berbagai upaya untuk mengatasi kecelakaan kerja di rumah sakit, salah satunya dengan dikeluarkannya Undang-Undang Nomor 23 Tahun 1992 dan Undang-Undang Nomor 36 Tahun 2009 tentang penerapan Kesehatan dan Keselamatan Kerja di rumah sakit (Kepmenkes RI, 2010, p.8). National Safety Council menyebutkan bahwa terjadinya kecelakaan dirumah sakit lebih besar dari pekerja di industry lain. Bentuk perilaku tidak aman pada perawat yang bekerja dirumah sakit yaitu tidak memakai sarung tangan ketika melakukan tindakan injeksi dan memasang infus serta tidak menggunakan sepatu yang sesuai. Faktor yang menyebabkan perawat berprilaku tidak aman yaitu sikap negative perawat yang tidak disiplin dalam menggunakan alat pelindung diri (ADP) dan Standar Operasional Prosedur (SOP) yang berlaku di Rumah sakit sesuai dengan standart Departemen Kesehatan RI tahun 2006.

Selain menerapkan keselamatan dan kesehatan kerja dirumah sakit, perawat juga di tuntut untuk memiliki pemahaman yang baik mengenai cara pencegahan kecelakaan serta penanganan yang dilakukan apabila kecelakaan terjadi. Pemahaman tersebut akan menimbulkan persepsi yang baik dalam diri perawat tentang K3 sehingga hal ini akan mengingkatkan perilaku perawat dalam menjaga keselamatan dan kesehatan dalam bekerja. 


\section{Upaya dalam melaksanakan Keselamatan dan Kesehatan Kerja}

Pelayanan keperawatan perlu upaya peningkatan mutu pelayanan rumah sakit melalui upaya peningkatan kualitas pelayanan keperawatan, dan profesionalisme perawat dalam memberikan dan mengatur kegiatan asuhan keperawatan kepada pasien. Tugas perawat dalam memberikan asuhan keperawatan antara lain mengkaji kebutuhan pasien, merencanakan tindakan keperawatan, melaksanakan rencana tindakan, mengevaluasi hasil asuhan keperawatan, mendokumentasikan asuhan keperawatan, berperan serta dalam melakukan penyuluhan, yang terangkum dalam sistem pengorganisasian. Untuk menciptakan perawat agar selalu berupaya memberikan pelayanan yang terbaik bagi pasien, maka pimpinan RSUD Arifin Achmad berusaha selalu menggunakan kewenangan untuk mengubah sikap dan perilaku karyawan agar berusaha lebih giat dan berkeinginan untuk mencapai hasil yang optimal. Dengan terciptanya kepuasan bagi perawat maka dengan tidak langsung perawat mampu memberikan kinerja yang berkualitas kepada pasien dalam bentuk pemenuhan kepuasan bagi pasien. Selain perawat agar berkualitas pimpinan juga harus memperhatikan kepuasan dari perawatnya sehubungan dengan hal ini, pemerintah banyak mengambil kebijaksanaan dan mengeluarkan peraturan-peraturan maupun pedoman yang semuanya ini dimaksudkan untuk meningkatkan kerja perawat dengan sebaik-baiknya.

\section{Penerapan Keselamatan Pasien di Rumah Sakit oleh Perawat}

Penerapan keselamatan pasien yang kurang efektif dapat terjadi pada identifikasi pasien, kesalahan dalam komunikasi, kesalahan titik operasi, kesalahan obat, infeksi di rumah sakit dan pasien jatuh. Potensi kesalahan biasa terjadi pada identifikasi pasien salah pemberian nama pasient, komunikasi pada saat discharge planning tidak lengkap, dan kurang pengontrolan pasien mengakibatkan pasien jatuh. Kesalahan penerapan keselamatan pasien terbanyak adalah komunikasi yang tidak efektif.

Identifikasi risiko dari tahapan layanan dan kondisi pasien harus dilakukan untuk menentukan tindakan pengurangan risiko. Pengendalian risiko merupakan bentuk penerapan keselamatan pasien sesuai standar dapat meningkatkan mutu asuhan keperawatan. Kinerja asuhan keperawatan yang baik akan meningkatkan efektifitas mutu keperawatan. Penerapan asuhan keperawatan layanan keperawatan Pelayanan keperawatan dengan penerapam keselamatan pasien dapat meminimalkan tingkat kesalahan dan berdampak pada penurunan biaya yang harus dibayar oleh pasien akibat masa rawat yang lama (Gerri, Kaufman \& Dorothy, 2013).

Pada keselamatan pasien mengurangi risiko infeksi akibat perawatan kesehatan masih ditemukan perawat yang tidak membersihkan tangan, terutama sebelum melakukan tindakan keperawatan dan pada kegiatan five moment yang lain seperti setelah masuk lingkungan ruang rawat. 
Kondisi yang telah digambarkan menunjukkan bahwa penerapan keselamatan pasien oleh perawat belum optimal dan kondisi ini diduga berdampak pada tingkat pasien.

\section{KESIMPULAN}

Pihak rumah sakit harus lebih memperhatikan hal-hal yang mendukung keselamatan dan kesehatan kerja perawat dalam melakukan pekerjaan mereka sebagai perawat. Dengan terciptanya kepuasan bagi perawat maka dengan tidak langsung perawat mampu memberikan kinerja yang berkualitas kepada pasien sehingga menjadi kepuasan bagi pasien. Perawat sangat berperan dalam peningkatan kualitas rumah sakit dan kepuasan pasien. Selain memberikan asuhan keperawat, perawat juga harus memperhatikan keselamatan pasien dengan berhati-hati dalam melakukan asuhan keperawatan.

\section{SARAN}

Adapun saran dari saya untuk profesi keperawatan sebaiknya terus mengembangkan pengetahuan dan keterampilan di bidang manajemen keperawatan khususnya terkaitKesehatan dan Keselamatan Kerja (K3) sehingga pelayanan yang diberikan dapat lebih optimal dan berkualitas tanpa melupakan tingkat kesehatan dan keselamatan bagi pemberi asuhan keperawatan.

Bagi rumah sakit sebaiknya selalu dapat memberikan dukungan dan memfasilitasi para perawat untuk dapat meningkatkan pengetahuan dengan pelatihan serta melatih keterampilannya sehingga dapat bekerja dengan lebih aman.

\section{DAFTAR PUSTAKA}

Firmansyah, I., Yulianti, D., \& Sela, R. B. (2017, November 2). Strategi Meningkatkan Komitmen Penerapan Kesehatan dan Keselamatan Kerja di Rumah Sakit X Tahun 2017. Jurnal Kesehatan, 10(2), 4-5.

Handayani, L. T. (2017, December). Analisis Jalur Keselamatan dan Kesehatan Kerja dengan Kepuasan Terhadap Kinerja Perawat dalam Memberikan Asuhan Keperawatan di RS Jember. The Indonesian Journal Of Health Science, 9(1), 43-46.

Nazirah, R., \& Yuswardi. (2017). Perilaku Perawat dalam Penerapan Manajemen Kesehatan dan Keselamatan Kerja (K3) di Aceh. Idea Nursing Journal, 8(3).

Nurhidayanti, D. (2017). Pengaruh Pelaksanaan Keselamatan dan Kesehatan Kerja (K3) Terhadap Kepuasan Kerja Perawat. JOM FISIP, 4(1), 3-6.

Rezeki, S. (2016). Kesehatan dan Keselamatan Kerja. Jakarta Selatan, Jakarta: Pusdik SDM Kesehatan.

Simamora, R. H. (2011). ROLE CONFLICT OF NURSE RELATIONSHIP WITH PERFORMANCE IN THE EMERGENCY UNIT OF HOSPITALS RSD DR. 
SOEBANDI JEMBER. 3(2), 2332.

Sriningsih, N., \& Marlina, E. (2020). PENGETAHUAN PENERAPAN KESELAMATAN PASIEN (PATIENT SAFETY) PADA PETUGAS KESEHATAN. Jurnal Kesehatan, 9(1).

Tanan, L., Indar, \& Darmawansyah. (2013). Analisis Tingkat Kepuasan Pasien di Puskesmas Bara Permai Kota Palopo. Jurnal AKK, 2(3), 1618.

Wibowo, E. (2016). Pengaruh Keselamatan Kerja dan Kesehatan Kerja terhadap Kinerja Dengan Kepuasan Kerja Sebagai Variabel Intervening. Jurnal Among Makarti, 9(17), 39-41.

Widiasari, Handayani, H., \& Novitestari, E. (2019). Kepuasan Pasien Terhadap Penerapan Keselamatan Pasien di Rumah Sakit. Jurnal Keperawatan Indonesia, 22(1), 4346.

Yvana, A., Widjasena, B., \& Jayanti, S. (2014, January). Analisa Komitmen Manajemen Rumah Sakit terhadap Keselamatan dan Kesehatan Kerja (K3) Pada RS Prima Medika Palembang. Jurnal Kesehatan Masyarakat, 2(1), 3640. 
